\title{
The microvilli of the small intestinal surface epithelium in coeliac disease and in idiopathic steatorrhoea
}

\author{
MARGOT SHINER AND M. S. C. BIRBECK \\ From the Department of Gastroenterology, Central Middlesex Hospital, London, and \\ the Chester Beatty Research Institute, London
}

SYNOPSIS This paper records the electron microscopic appearances in patients with coeliac disease and idiopathic steatorrhoea, and draws attention to the changes in the microvilli.

The existence of rod-shaped extensions of the free surface of the villous cells, forming the brush border, has been known since 1857 when Brettauer and Steinach first reported their studies in rabbits, guinea-pigs, dogs, and man. This was confirmed by Granger and Baker (1949) in the first electron microscope investigation of the intestinal epithelium of rats. They demonstrated the brush border as cylindrical perpendicular projections with rounded apices, averaging $0.62 \mu$ in length and $0.08 \mu$ in width, and estimated the number of projections as 3,000 per cell. Zetterquist (1956) found these projections, or microvilli, in fasting mice to be of variable length (average $0.91 \pm 0.09 \mu$ ) though more constant in width (average $0 \cdot 10 \pm 0.003 \mu$ ). He estimated 650-700 microvilli per cell, increasing its absorbing surface by about 14 times. Palay and Karlin (1959) described the microvilli in rats as regular, evenly packed, rod-like projections whose cytoplasm is continuous with that of the main cell. Their average length was $1 \mu$ and their width $0.07 \mu$. The estimated number of projections per cell was 1,000 , increasing its absorptive surface by a factor of 24. Hartman, Butterworth, Hartman, Crosby, and Shirai (1960) reported in the human a range of microvillous height of 0.8 to $1.3 \mu$ (15 normal and four non-sprue patients) with a maximal width of $0 \cdot 12 \mu$. It is clear that one of the functions of the microvilli would be to increase the absorptive area to a considerable degree and any reduction in size or number of the microvilli would impede the efficient absorption of food.

Hartman et al. (1960) studied the surface epithelium with the electron microscope of a patient with non-tropical sprue or idiopathic steatorrhoea before treatment and five days after the start of a gluten-free diet. They found the brush border abnormal in both instances. In addition, they found an abnormality in a proportion of mitochondria in the apical cytoplasm of the cells, as well as some unidentified bodies and granules not present in the 'normal' cell. Zetterquist and Hendrix (1960) observed stunted microvilli to be a feature of non-tropical sprue in one patient, becoming normal after treatment with a gluten-free diet. We are here reporting on our findings of the appearances of the microvilli in seven 'control' patients, eight patients with coeliac disease, and seven patients with adult idiopathic steatorrhoea or non-tropical sprue. In the last two groups we have studied the brush border in relation to treatment with a gluten-free diet.

\section{METHOD AND MATERIAL}

All 22 patients were fasted for 12 hours and were then intubated with the peroral small intestinal biopsy tube (Shiner, 1956) and multiple specimens were obtained from the last part of the duodenum or upper jejunum. Fixation of the specimens was begun within two to five minutes after cutting off the specimens from their blood supply. The biopsies from each patient were fixed in a $10 \%$ solution of formal saline for light microscopy and in $1 \%$ osmium tetroxide buffered at $p \mathrm{H} 7 \cdot 4$ (Palade, 1952). Only those specimens showing adequately preserved surface epithelium on light microscopy were included in this study so that their appearances could be compared with those of the electron microscope. The epithelial cell heights were measured with a micrometer by light microscopy and the average of 10 cell counts per biopsy per patient was determined. 
For the electron microscope, after fixation in $1 \%$ osmium tetroxide for two hours the tissue was washed briefly and then dehydrated in ethanol. Because of the large size of the specimens, they were trimmed at this stage at their periphery and small pieces of tissue, less than $0.5 \mathrm{~mm}$., were embedded in araldite (Glauert, Rogers, and Glauert, 1956). Sections were cut and placed on a grid for examination on a Siemens E.M. 100 electron microscope. Some of these sections were stained with lead hydroxide on the grid. Several micrographs $(\times 8,000)$ were taken of the microvilli and the epithelial cells from each patient. The sites chosen for micrography were those of the tips and sides of intestinal villi, where present. The micrographs were enlarged to $32,000 \times$ and from the prints measurements were made of the length of the microvilli. The distance measured was taken from a line running through the tips of the microvilli to the level of the plasma membrane from which the microvilli project. Measurements of the number of microvilli per cell or unit area were not made because variation in shape of microvilli, found in the pathological specimens of our group but not in the normal ones, made it impossible to be accurate.

The appearances and measurements of the microvilli were recorded by one of the authors independently of the other author's assessment of the patient's clinical state, the overall histological appearances of the mucosal biopsies, and the measurements of surface cell heights.

Of the seven patients chosen as controls (Table I), five did not suffer from steatorrhoea, in one patient (F.T.) who was symptomless, faecal fat estimations were not done, but one patient (C.G.), with extensive ulcerative colitis probably involving the terminal ileum, had mild steatorrhoea. Histologically this group showed a normal mucosa, although in two (F.T. and G.D.) the villi appeared shorter or more irregular than normal.

The ages of the eight children with coeliac disease ranged from 12 months to 11 years 10 months. Only two patients (J.N. and V.B.) were untreated at the time of biopsy. In the other six children the duration of treatment with a gluten-free diet was correlated to the time of biopsy. All six were in clinical remission but only one (J.L.) showed no gluten sensitivity, demonstrated by continued good progress after gluten had again been introduced into the diet. Gluten sensitivity was not tested in McG.A.

Of the seven patients with idiopathic steatorrhoea, three were untreated and in clinical relapse at the time of biopsy. The other four had received a gluten-free diet from one to six months before biopsy. Two of these (M.W. and J.B.) were in remission, one (E.A.) showed no response clinically or biochemically, and one (J.J.) had been in clinical remission before it was decided to put him on the diet, though his stools, which were formed, contained an excess amount of fat.

\section{RESULTS}

LIGHT MICROSCOPY The light microscopy appearances of the specimens from the 'control' group (Fig. 1) consisted of long slender villi, covered by tall columnar epithelium (Doniach and Shiner, 1957).

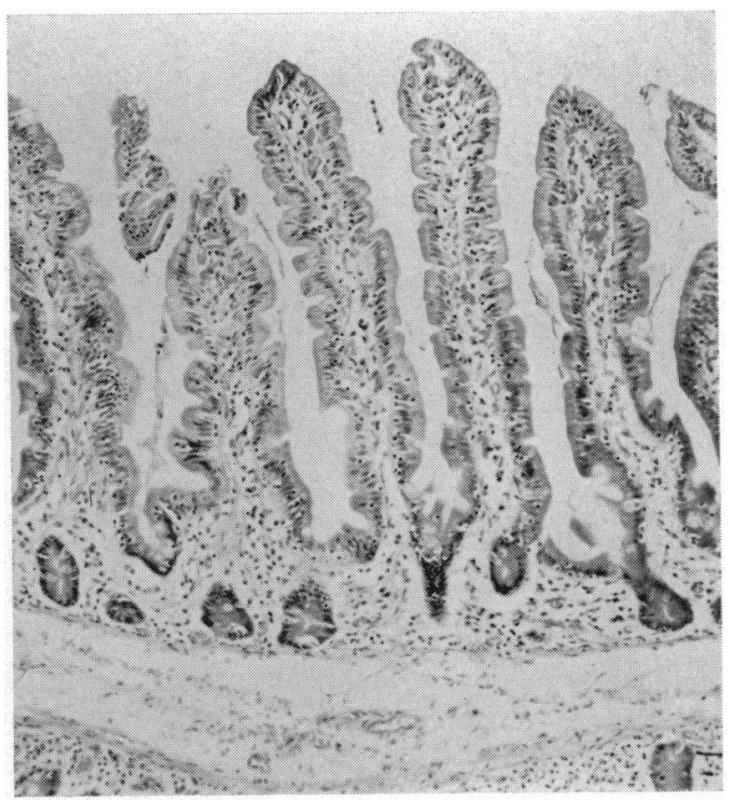

FIG. 1. Normal mucosa of the upper jejunum. Haematoxylin and eosin $\times 100$.

The epithelial cell height measured on the average $35.8 \mu$ with a range of $31.0 \mu$ to $42.9 \mu$ (Table I). The cell nuclei appeared elongated, dark staining, and basally situated. The brush border was not studied with the light microscope. A few goblet cells were interspersed between the villous cells. The mucosal layer showed a thickness about one fourth of the height of the villi and contained scanty glands of Lieberkühn.

The histological appearances in the coeliac group (Shiner, 1960) showed a varied picture. In the untreated children (J.N. and V.B.) villi had almost completely disappeared and mucosal thickness had increased with hyperplasia of the glands of Lieberkühn. The surface epithelium appeared low columnar, cuboidal, or stratified, and the nuclei showed gross irregularity in size and position. The surface cell height measured less than half the nornal (Fig. 2). In J.L., treated with a gluten-free diet for six years and showing no sensitivity to gluten when wheat was re-introduced, the biopsy was normal, as was the surface cell height. Of four children treated with a gluten-free diet for four to nine years but remaining sensitive to gluten, two showed a normal biopsy with normal cell height measurements, and two had subtotal villous atrophy with reduced surface cell height and irregular nuclei. In one child (McG.A.), on a gluten-free diet for only two years, sensitivity to gluten was not tested. 
TABLE I

$\begin{array}{llll}\text { Patient Diagnosis } & \text { Clinical } & \text { Steatorrhoea Treatment } & \text { Light Microscopy } \\ \text { State } & \checkmark & \text { Histology } \begin{array}{l}\text { Surface Cell } \\ \text { Heights }(\mu)\end{array}\end{array}$

Electron Microscopy

Comments

Length of Regularity of

( $\mu$ )

\begin{tabular}{|c|c|c|c|c|c|c|c|c|c|}
\hline $\begin{array}{l}\text { C.B. } \\
\text { M } 36\end{array}$ & $\begin{array}{l}\text { Folic acid } \\
\text { deficiency }\end{array}$ & $\begin{array}{l}\text { Megaloblastic } \\
\text { anaemia }\end{array}$ & Absent & $\begin{array}{l}\text { Vitamin } B_{12} \text {, } \\
\text { folic acid }\end{array}$ & Normal & $32 \cdot 3$ & 1.09 & $\begin{array}{l}\text { Regular and } \\
\text { tightly packed }\end{array}$ & \\
\hline $\begin{array}{l}\text { M.M. } \\
\text { F } 29\end{array}$ & $\begin{array}{l}\text { Diarrhoea } \\
\text { ? cause }\end{array}$ & $\begin{array}{l}\text { Diarrhoea and } \\
\text { weight loss }\end{array}$ & Absent & $\begin{array}{l}\text { G.F.D., } \\
\text { folic acid }\end{array}$ & Normal & $38 \cdot 0$ & 1.03 & $\begin{array}{l}\text { Regular and } \\
\text { tightly packed }\end{array}$ & \\
\hline $\begin{array}{l}\text { A.H. } \\
\text { M } 46\end{array}$ & $\begin{array}{l}\text { Haemate- } \\
\text { mesis }\end{array}$ & $\begin{array}{l}\text { Iron-deficiency } \\
\text { anaemia }\end{array}$ & Absent & Nil & Normal & $31 \cdot 0$ & 1.09 & $\begin{array}{l}\text { Regular and i } \\
\text { tightly packed }\end{array}$ & \\
\hline $\begin{array}{l}\text { W.R. } \\
\text { M } 56\end{array}$ & $\begin{array}{l}\text { Haemochro- } \\
\text { matosis }\end{array}$ & Well & Absent & Bleeding & Normal & $37 \cdot 6$ & 1.09 & $\begin{array}{l}\text { Regular and } \\
\text { tightly packed }\end{array}$ & \\
\hline $\begin{array}{l}\text { C.G. } \\
\text { M } 15\end{array}$ & $\begin{array}{l}\text { Ulcerative } \\
\text { colitis }\end{array}$ & In relapse & Present & Prednisone & Normal & $42 \cdot 9$ & $1 \cdot 19$ & $\begin{array}{l}\text { Regular and } \\
\text { tightly packed }\end{array}$ & \\
\hline $\begin{array}{l}\text { G.D. } \\
\text { M } 61\end{array}$ & $\begin{array}{l}\text { Pernicious } \\
\text { anaemia }\end{array}$ & $\begin{array}{l}\text { Megaloblastic } \\
\text { anaemia }\end{array}$ & Absent & Vitamin $\mathbf{B}_{12}$ & ? Normal & $31 \cdot 7$ & 0.75 & $\begin{array}{l}\text { Regular and } \\
\text { tightly packed }\end{array}$ & $\begin{array}{l}\text { Variable size } \\
\text { of villi }\end{array}$ \\
\hline $\begin{array}{l}\text { F.T. } \\
\text { M } 36 \\
\text { (staff) }\end{array}$ & & $\begin{array}{l}\text { Symptom } \\
\text { free }\end{array}$ & Not tested & - & ? Normal & $37 \cdot 3$ & 0.84 & Variable & $\begin{array}{l}\text { Variable size } \\
\text { of villi }\end{array}$ \\
\hline $\begin{array}{l}\text { J.N. } \\
\text { F } 2 \frac{1}{2}\end{array}$ & $\begin{array}{l}\text { Coeliac } \\
\text { disease }\end{array}$ & In relapse & Present & Nil & S.V.A. & $15 \cdot 5$ & 0.75 & $\begin{array}{l}\text { Irregular and } \\
\text { loosely packed }\end{array}$ & \\
\hline $\begin{array}{l}\text { V.B. } \\
\text { F } 1\end{array}$ & $\begin{array}{l}\text { Coeliac } \\
\text { disease }\end{array}$ & In relapse & Present & Nil & S.V.A. & $21 \cdot 1$ & 0.90 & Loosely packed & \\
\hline $\begin{array}{l}\text { J.L. } \\
\text { M } 10\end{array}$ & $\begin{array}{l}\text { Coeliac } \\
\text { disease }\end{array}$ & Remission & Absent & $\begin{array}{l}\text { G.F.D. for } \\
6 \text { years }\end{array}$ & Normal & $34 \cdot 3$ & 1.03 & $\begin{array}{l}\text { Regular and } \\
\text { tightly packed }\end{array}$ & $\begin{array}{l}\text { No gluten } \\
\text { sensitivity }\end{array}$ \\
\hline $\begin{array}{l}\text { L.C. } \\
\text { F } 12\end{array}$ & $\begin{array}{l}\text { Coeliac } \\
\text { disease }\end{array}$ & Remission & Absent & $\begin{array}{l}\text { G.F.D. for } \\
9 \text { years }\end{array}$ & Normal & $34 \cdot 0$ & 0.87 & $\begin{array}{l}\text { Regular but } \\
\text { loosely packed }\end{array}$ & $\begin{array}{l}\text { Gluten } \\
\text { sensitive }\end{array}$ \\
\hline $\begin{array}{l}\text { D.B. } \\
\text { M } 10 \frac{1}{2}\end{array}$ & $\begin{array}{l}\text { Coeliac } \\
\text { disease }\end{array}$ & Remission & Atsent & $\begin{array}{l}\text { G.F.D. for } \\
4 \text { years }\end{array}$ & Normal & 41.9 & 0.84 & $\begin{array}{l}\text { Regular but } \\
\text { loosely packed }\end{array}$ & $\begin{array}{l}\text { Gluten } \\
\text { sensitive }\end{array}$ \\
\hline $\begin{array}{l}\text { B.D. } \\
\text { F } 10\end{array}$ & $\begin{array}{l}\text { Coeliac } \\
\text { disease }\end{array}$ & Remission & Absent & $\begin{array}{l}\text { G.F.D. for } \\
7 \text { years }\end{array}$ & S.V.A. & $21 \cdot 5$ & 0.70 & $\begin{array}{l}\text { Regular and } \\
\text { tightly packed }\end{array}$ & $\begin{array}{l}\text { Gluten } \\
\text { sensitive }\end{array}$ \\
\hline $\begin{array}{l}\text { S.H. } \\
\text { F } 10\end{array}$ & $\begin{array}{l}\text { Coeliac } \\
\text { disease }\end{array}$ & Remission & Absent & $\begin{array}{l}\text { G.F.D. for } \\
8 \text { years }\end{array}$ & S.V.A. & $23 \cdot 1$ & 0.62 & $\begin{array}{l}\text { Irregular and } \\
\text { loosely packed }\end{array}$ & $\begin{array}{l}\text { Gluten } \\
\text { sensitive }\end{array}$ \\
\hline $\begin{array}{l}\text { Mc.G.A. } \\
\text { F } 10\end{array}$ & $\begin{array}{l}\text { Coeliac } \\
\text { disease }\end{array}$ & Remission & Absent & $\begin{array}{l}\text { G.F.D. for } \\
2 \text { years }\end{array}$ & S.V.A. & $22 \cdot 8$ & 0.85 & $\begin{array}{l}\text { Irregular and } \\
\text { loosely packed }\end{array}$ & $\begin{array}{l}\text { Gluten } \\
\text { sensitivity } \\
\text { not tested }\end{array}$ \\
\hline $\begin{array}{l}\text { G.H. } \\
\text { M } 43\end{array}$ & $\begin{array}{l}\text { Idiopathic } \\
\text { steatorrhoea }\end{array}$ & In relapse & Present & $\begin{array}{l}\text { A.C.T.H., } \\
\text { folic acid }\end{array}$ & S.V.A. & $27 \cdot 1$ & 0.62 & $\begin{array}{l}\text { Rogular but } \\
\text { loosely packed }\end{array}$ & $\ldots$ \\
\hline $\begin{array}{l}\text { M.M. } \\
\text { M } \mathbf{3 0}\end{array}$ & $\begin{array}{l}\text { Idiopathic } \\
\text { steatorrhoea }\end{array}$ & In relapse & Present & $\begin{array}{l}\text { Vitamin } B_{12} \text {, } \\
\text { folic acid }\end{array}$ & S.V.A. & $28 \cdot 1$ & 0.47 & $\begin{array}{l}\text { Regular but } \\
\text { loosely packed }\end{array}$ & \\
\hline $\begin{array}{l}\text { F.D. } \\
\text { M } 62\end{array}$ & $\begin{array}{l}\text { Idiopathic } \\
\text { steatorrhoea }\end{array}$ & In relapse & Present & Nil & S.V.A. & $31 \cdot 7$ & 0.87 & $\begin{array}{l}\text { Regular and } \\
\text { tightly packed }\end{array}$ & \\
\hline $\begin{array}{l}\text { E.A. } \\
\text { F } 75\end{array}$ & $\begin{array}{l}\text { Idiopathic } \\
\text { steatorrhoea }\end{array}$ & In relapse & Present & $\begin{array}{l}\text { Vitamin } \mathbf{B}_{12} \text {, } \\
\text { folic acid, } \\
\text { G.F.D. } 6 \text { mth. }\end{array}$ & S.V.A. & $27 \cdot 1$ & 0.87 & $\begin{array}{l}\text { Regular but } \\
\text { loosely packed }\end{array}$ & $\begin{array}{l}\text { No response } \\
\text { to gluten- } \\
\text { free diet }\end{array}$ \\
\hline $\begin{array}{l}\text { J.J. } \\
\mathbf{M} 70\end{array}$ & $\begin{array}{l}\text { Idiopathic } \\
\text { steatorrhoea }\end{array}$ & $\begin{array}{l}\text { Partial remis- } \\
\text { sion }\end{array}$ & Present & $\begin{array}{l}\text { Vitamin } \text { B }_{12} \\
\text { folic acid, } \\
\text { G.F.D. } 1 \mathrm{mth} \text {. }\end{array}$ & S.V.A. & $24 \cdot 8$ & 0.78 & $\begin{array}{l}\text { Regular and } \\
\text { tightly packed }\end{array}$ & $\begin{array}{l}\text { Uncertain } \\
\text { response to } \\
\text { gluten-free } \\
\text { diet }\end{array}$ \\
\hline $\begin{array}{l}\text { M.W. } \\
\text { F } 65\end{array}$ & $\begin{array}{l}\text { Idiopathic } \\
\text { steatorrhoea }\end{array}$ & Remission & Absent & $\begin{array}{l}\text { G.F.D. } \\
6 \text { mth. }\end{array}$ & P.V.A. & 35.0 & 0.85 & $\begin{array}{l}\text { Regular and } \\
\text { tightly packed }\end{array}$ & $\begin{array}{l}\text { Pre-treat- } \\
\text { ment biopsy } \\
\text { showed } \\
\text { S.V.A. }\end{array}$ \\
\hline $\begin{array}{l}\text { J.B. } \\
\text { F } 34\end{array}$ & $\begin{array}{l}\text { Idiopathic } \\
\text { steatorrhoea }\end{array}$ & Remission & $\begin{array}{l}\text { Not } \\
\text { repeated }\end{array}$ & $\begin{array}{l}\text { G.F.D. } \\
2 \text { mth. }\end{array}$ & S.V.A. & $29 \cdot 4$ & 0.80 & $\begin{array}{l}\text { Irregular and } \\
\text { loosely packed }\end{array}$ & $\begin{array}{l}\text { Good pro- } \\
\text { gress on } \\
\text { G.F.D. }\end{array}$ \\
\hline
\end{tabular}

G.F.D. = gluten-free diet

S.V.A. = subtotal villous atrophy

P.V.A. = partial villous atrophy

idiopath. steatorrh. = idiopathic steatorrhoea 


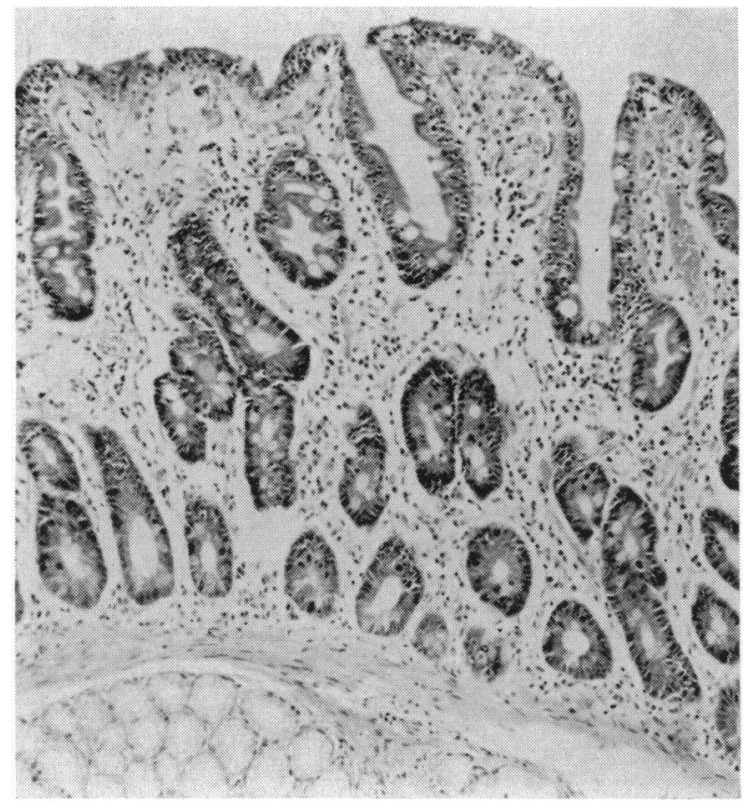

FIG. 2. Subtotal villous atrophy in coeliac disease. Haematoxylin and eosin $\times 100$.

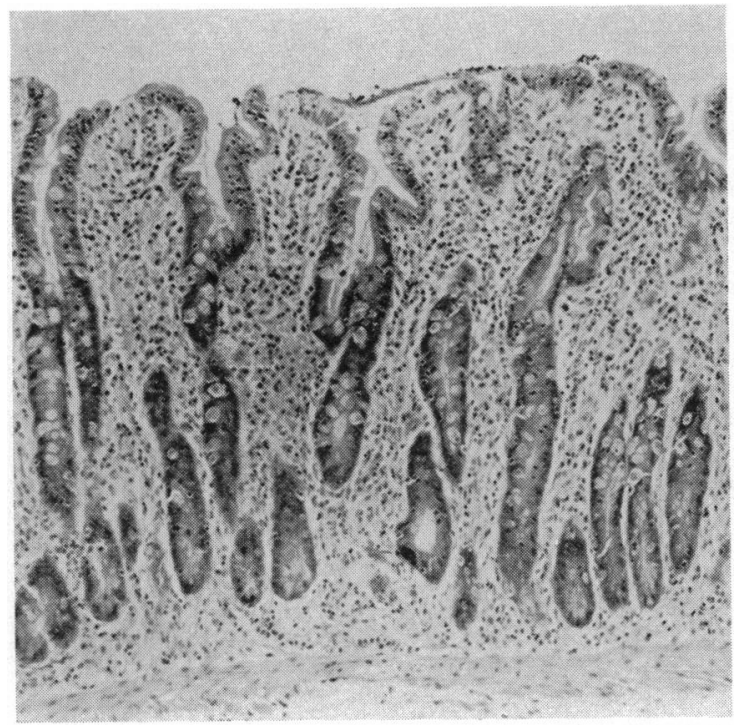

FIG. 3. Subtotal villous atrophy in idiopathic steatorrhoea. Haematoxylin and eosin $\times 100$.
In all three patients with idiopathic steatorrhoea untreated with a gluten-free diet, the biopsies showed subtotal villous atrophy (Fig. 3), reduction of surface cell height, and irregularity of the nuclei (Shiner and Doniach, 1960). The biopsies of two of the four patients with idiopathic steatorrhoea treated with a gluten-free diet for one to six months but showing no clinical or biochemical response during that time or after, had the same histopathological appearances as the untreated group. In the biopsies of the remaining two patients on a gluten-free diet with good clinical response, one (M.W.) showed a partial villous atrophy where a pre-treatment biopsy had shown subtotal villous atrophy. The surface epithelium showed improvement in height and nuclear regularity over the pre-treatment biopsy and the surface cell height was within normal limits. The other (J.B.) showed a subtotal villous atrophy in spite of the patient's improved clinical state. The average surface cell height of all biopsies in the coeliac-idiopathic group was $27 \cdot 8 \mu$.

ELECTRON MICROSCOPY Electron micrographs of the seven contiol patients showed normal cytological structure of the villous epithelium. In the biopsies of five patients the microvilli had a length of 1.03 to $1 \cdot 19 \mu$ and were regular in size and shape as well as tightly packed (Fig. 4). The other two (F.T. and G.D.), however, had a microvillous length of $0.75 \mu$ and $0.84 \mu$ respectively although the regularity in spacing of microvilli was considered normal (Fig. 5). These two sections also showed shortening and irregularity of villi under the light microscope, and one an unusual variation in length of microvilli, from $0.78 \mu$ to $0.94 \mu$. In neither of these two sections was there any evidence of other abnormal structures and the nuclei, mitochondria, golgi region, and cell membranes of the epithelium appeared normal.

The appearances of the microvilli in the biopsies of eight coeliac children were variable. In only one child (J.L.) were they of normal length and this correlated well with the patient's complete clinical remission, absence of sensitivity to gluten, and normal appearances of the mucosa on light microscopy. The biopsies of the remaining seven patients had shortened microvilli, measuring $0.75,0.70,0.90$, 0.62 , and $0.85 \mu$ respectively in those which also demonstrated subtotal villous atrophy on light microscopy, and $0.87 \mu$ and $0.84 \mu$ in those with normal mucosal appearances (Fig. 6). Variation in the packing of microvilli was seen in all but one biopsy. In one instance (patient S.H.) dense granules were seen in the cytoplasm of the surface cells and these were present also in one case with idiopathic steatorrhoea. 


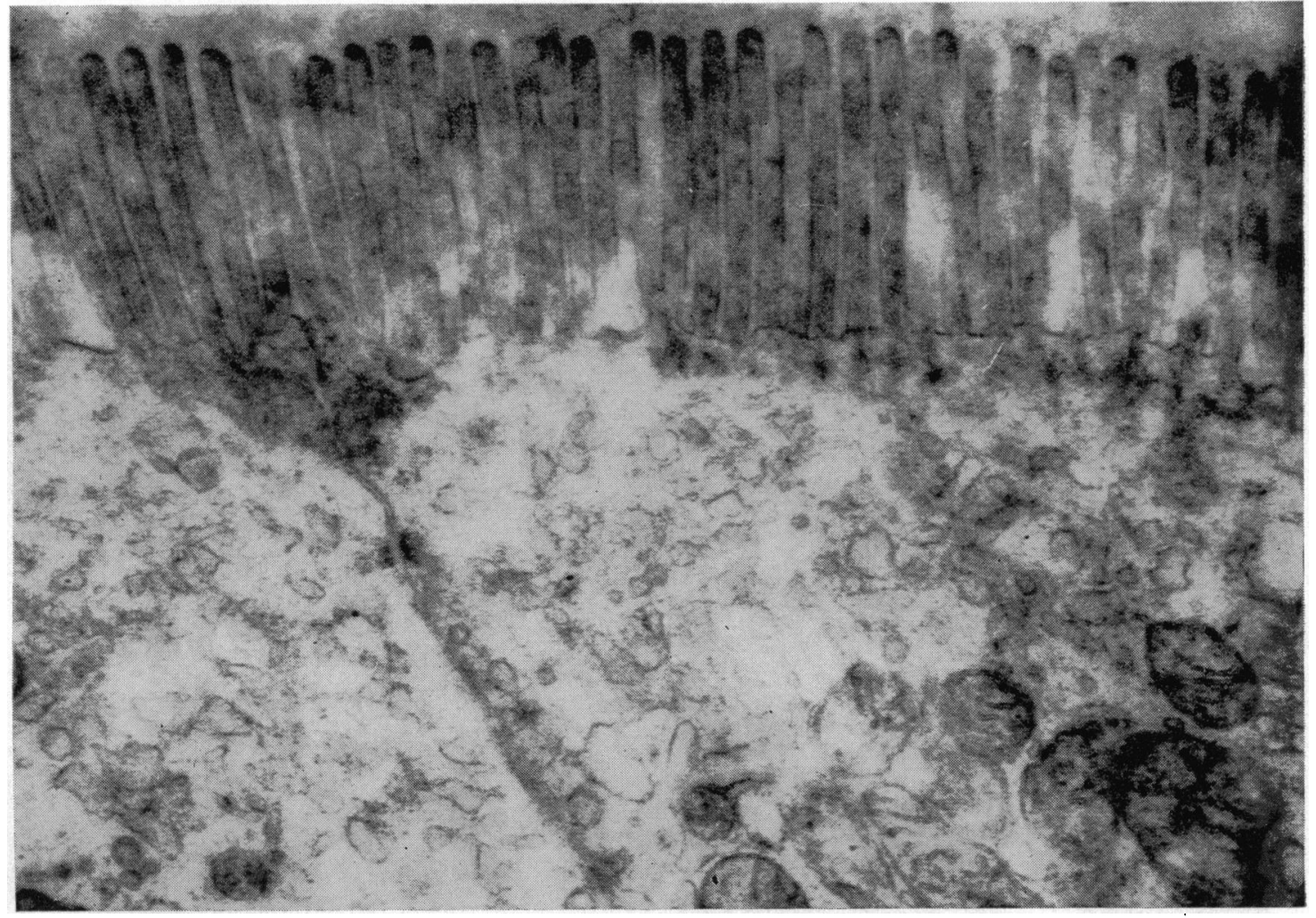

FIG. 4. Electron micrograph from control case C.B. showing normal microvilli and upper part of small intestinal surface cell $\times 32,000$.

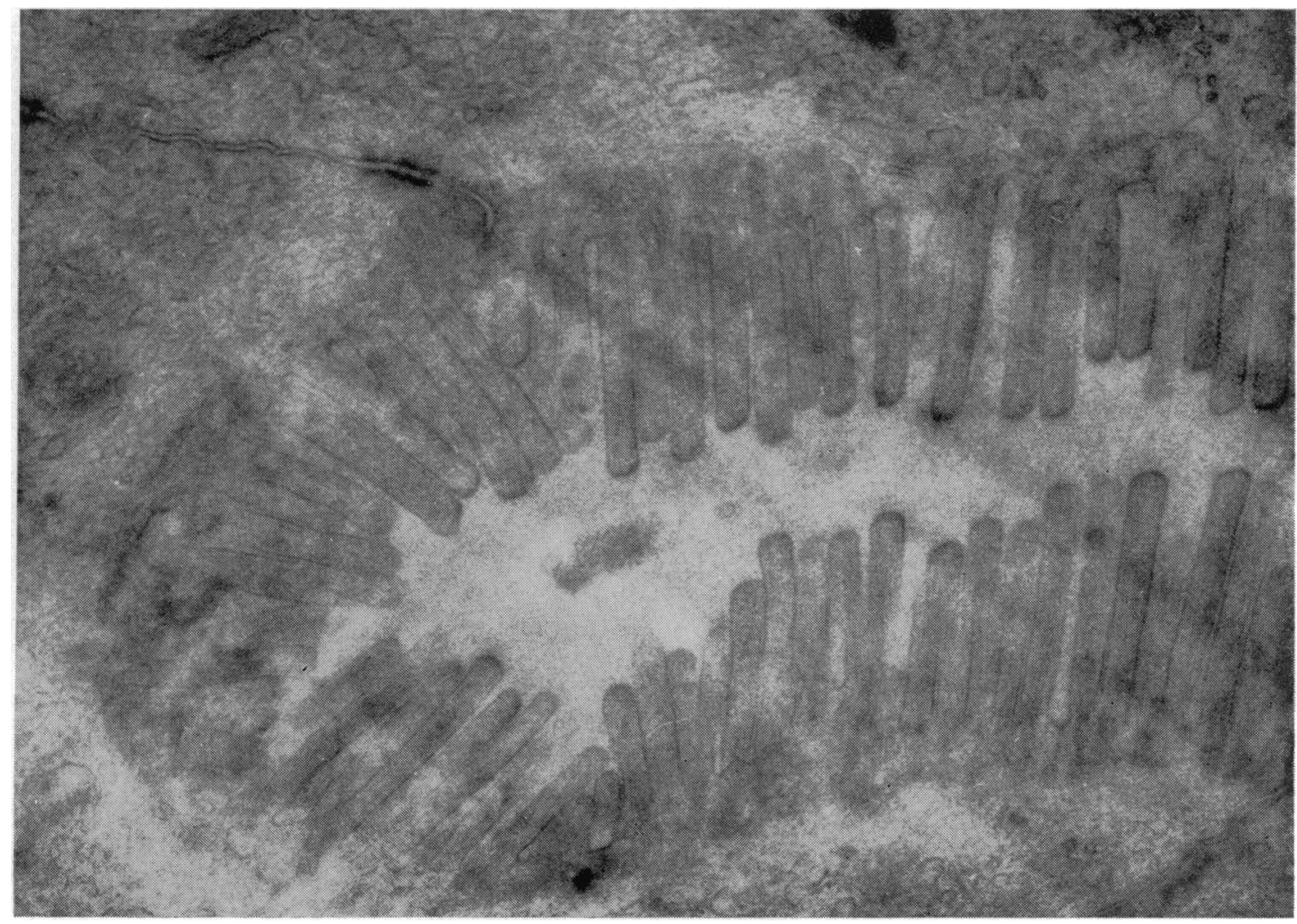

FIG. 5. Electron micrograph from control case F.T. showing short, though regular microvilli with variation in length $\times 32,000$. 


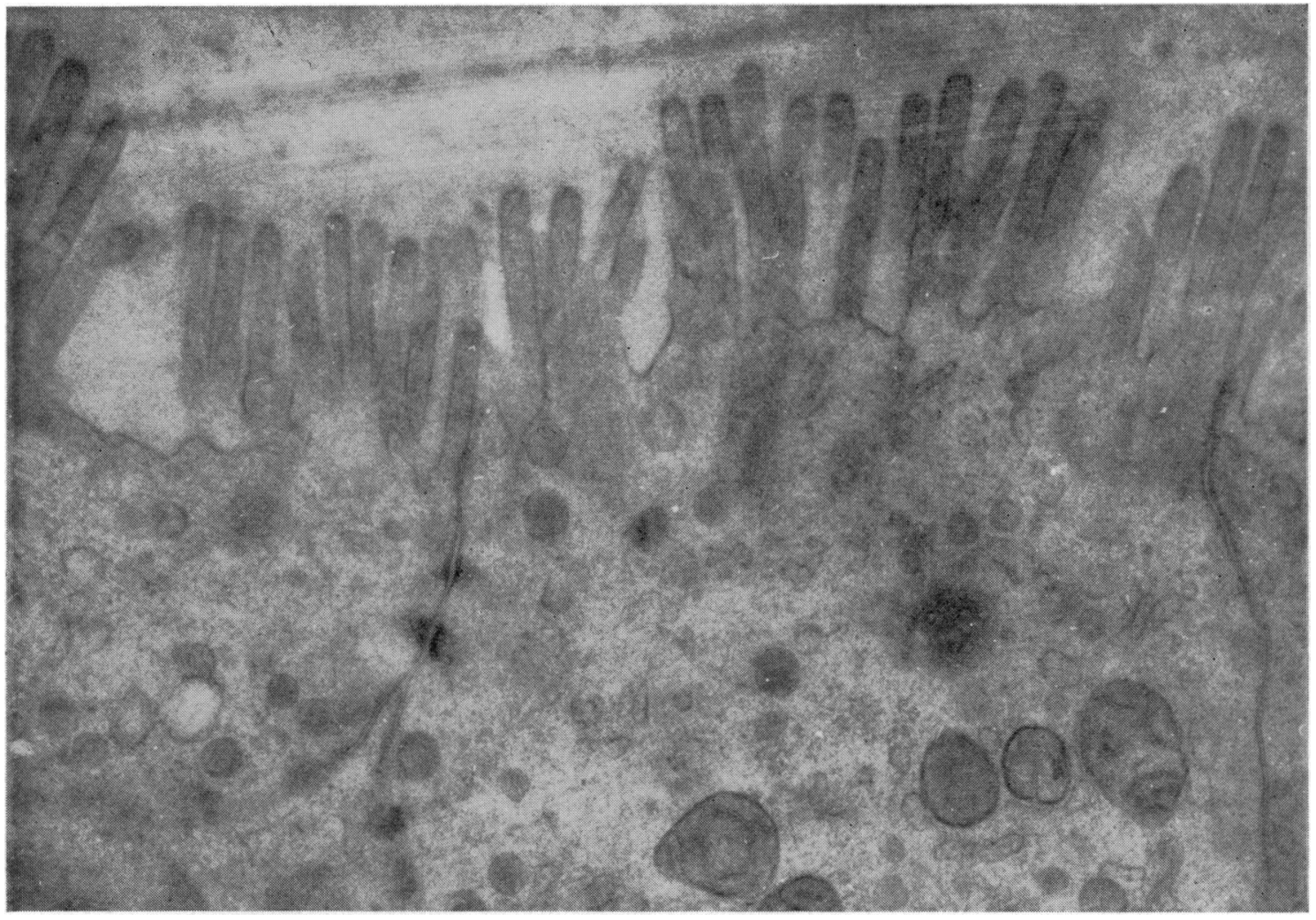

FIG. 6. Electron micrograph from coeliac patient J.N. showing short, irregular and loosely packed microvilli $\times 32,000$.

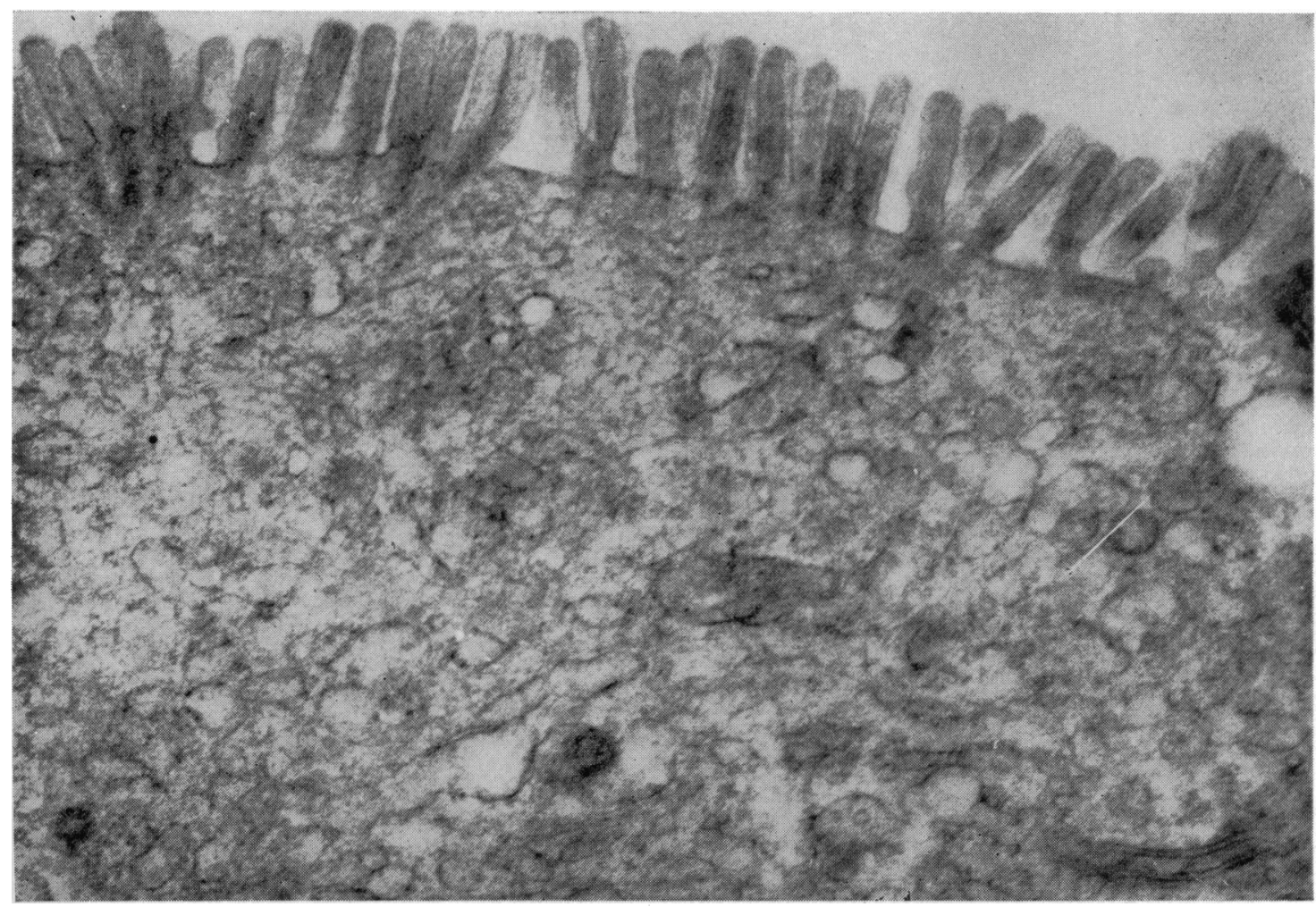

FIG. 7. Electron micrograph from patient M.M. with idiopathic steatorrhoea showing greatly shortened and slightly wider microvilli which are regular and loosely packed $\times 32,000$. 
In biopsies from all seven patients with idiopathic steatorrhoea the length of microvilli was reduced, varying from $0.47 \mu$ to $0.87 \mu$. The shortest microvilli were found in those of the untreated patients, in relapse at the time of biopsy. In the biopsy from one treated patient (M.W.) with partial villous atrophy the microvilli remained shorter than normal $(0.85 \mu)$, despite the histological improvement over a previous pre-treatment biopsy. Sections of four out of the seven patients showed irregularity in size of microvilli and density of their spacing (Fig. 7).

As in the coeliac group, the cytoplasmic appearances in idiopathic steatorrhoea were, on the whole, normal. Peculiar granules and somewhat pathological nuclei could be demonstrated in one of three untreated patients (G.H.) and very abnormal cytoplasm and nuclei in a second (M.M.). These two sections also showed the shortest microvilli of this group, $0.62 \mu$ and $0.47 \mu$ respectively.

\section{DISCUSSION}

The mucosa in idiopathic steatorrhoea and untreated coeliac disease shows almost invariably a villous atrophy, which is usually subtotal but sometimes partial (Shiner and Doniach, 1960). Repeat mucosal biopsies in idiopathic steatorrhoea after gluten-free diets have shown improvement in some patients investigated by one of us; broad, though stunted villi have reappeared and taller surface cell epithelium with more regular nuclei. But complete mucosal normality has never been seen. In untreated coeliac disease the degree of villous atrophy is usually more severe than in the adult untreated or treated idiopathic steatorrhoea, but first biopsies in patients treated with a gluten-free diet over a long period of time have shown a more variable histological picture, ranging from subtotal villous atrophy to normal (Shiner, 1960). These appearances could not be correlated with the clinical state of the child. Repeat biopsies in one coeliac patient on a gluten-free diet over a period of three years showed considerable histological improvement though the overall appearances remained abnormal. Reports from other centres (Rubin, Brandborg, Phelps, Taylor, Murray, Stemler, Howrie, and Volwiler, 1960; Anderson, 1960) have indicated a possible return to histological normality after treatment with a gluten-free diet in coeliac disease.

Despite the abnormal light microscopy appearances of the surface cells and their nuclei in both coeliac disease and idiopathic steatorrhoea, the structural abnormalities of these cells under the electron microscope were less striking. The cell membrane, cytoplasmic inclusions, mitochondria, and Golgi apparatus appeared normal in 12 of the
15 patients with coeliac disease or idiopathic steatorrhea. However, the nuclei varied somewhat from the normal oval shape in being rounder, more irregular in outline, and often indented. The most striking abnormalities, however, appeared to be in the microvilli, where a reduction in height of these could be demonstrated in sections from 14 out of 15 patients with coeliac disease and idiopathic steatorrhoea and considerable irregularity and looseness of packing of microvilli in eight out of the 15 patients' biopsies.

Considering the coeliac disease-idiopathic steatorrhoea groups together, it has been shown (Table I) that the shortest microvilli were found in the untreated cases, which also exhibited a significant degree of irregularity. Amongst the treated patients only one out of 10 showed normal microvilli. The other nine had persistent abnormalities of microvilli, irrespective of the histological appearances, which ranged fiom normal to subtotal villous atrophy.

In the past few years much discussion has centred around the morphological cause of villous atrophy. It is known that the cells of the glands of Lieberkühn, which show active mitosis, produce the columnar cells of the villi, in which mitosis is never seen. The cells at the tip of the villi are therefore older than those at the crypt and are eventually extruded into the lumen. An absence or stunting of the villi could be due to decreased viability of the surface cells or diminished production of these. We have not found any evidence of increased destruction or disintegration of surface cells in coeliac disease or idiopathic steatorrhoea which would lead us to postulate decreased viability of these cells. With the light microscope it is common to observe a disintegrated cell being extruded at the tip of a normal villus, but in the villous atrophy of coeliac disease or idiopathic steatorrhoea this is not so evident. There is evidence only of shortening of microvilli, some alteration in nuclear shape, and shortening of the overall cell height. Diminished production of surface cells as a cause of villous atrophy is the more likely explanation, coupled perhaps with an abnormal production of cells which show a reversion from the highly differentiated columnar type to the more undifferentiated cuboidal or even stratified types. This occurs despite an apparent hypertophy of the glandular cells which show an increase rather than a decrease in mitotic figures (Shiner and Doniach, 1960). A similar relationship exists between the red cell precursors in the bone marrow and the peripheral megaloblasts or macrocytes in pernicious anaemia. As in this disease, the cause might be arrested maturation of the crypt cells and an actual slowing in certain phases of mitosis. 
Biopsies of the mucosa of the small intestine of 22 patients were subjected to light and electron microscopic studies. The patients were grouped into "controls', coeliac disease, and idiopathic steatorrhoea, and in the last two groups the clinical condition and therapeutic progress was recorded. Electron microscopic studies were directed mainly towards the microvilli of the surface epithelium. It was found that the latter were decreased in height in coeliac disease and idiopathic steatorrhoea and showed greater irregularity in shape and spacing. A good correlation existed between the light microscope appearances of villous atrophy and decrease in surface cell height and the electron microscope findings of microvillous abnormalities.

Our thanks are due to the many physicians who kindly referred their patients to us for investigation, to Dr. R. A. B. Drury and Mr. J. E. Mayhew for the histology, and Mrs. S. Roberts for preparing the electron microscopy sections.

One of us (M.S.) is working with a grant from the Medical Research Council to which grateful acknowledgements are herewith made.
Anderson, C. M. (1960). Histological changes in the duodenal mucosa in coeliac disease. Arch. Dis. Childh., 35, 419.

Brettauer, J., and Steinach, S. (1857). Untersuchungen über das Cylinderapithelium der Darmzotten und seine Beziehung zur fettresorption. S.-B. Akad. Wiss. Wien, math.-nat. Kl., 23, 303.

Doniach, I., and Shiner, M. (1957). Duodenal and jejunal biopsies II. Histology. Gastroenterology, 33, 71.

Glauert, A. M., Rogers, G. E., and Glauert, R. H. (1956). A new embedding medium for electron microscopy. Nature (Lond.), $178,803$.

Granger, B., and Baker, R. F. (1949). Electron microscope investigation of the striated border of intestinal epithelium. Anat. Rec. $103,459$.

Hartman, R. S., Butterworth, C. E., Hartman, R. E., Crosby, W. H. and Shirai, A. (1960). An electron microscope investigation of the jejunal epithelium in sprue. Gastroenterology, 38, 506.

Palade, G. E. (1952). A study of fixation for electron microscopy. J. exp. Med., 95, 285.

Palay, S. L., and Karlin, L. J. (1959). An electron microscopic study of the intestinal villus. I. The Fasting animal. J. biophys. biochem. Cytol., 5, 363.

Rubin, C. E., Brandborg, L. L., Phelps, P., Taylor, H. C. Jr., Murray, C.V., Stemler, R., Howrie, C., and Volwiler, W. (1960). Studies in coeliac disease II. Gastroenterology, 38, 517.

Shiner, M. (1956). Duodenal biopsy, Lancet, 1, 17 and 85.

(1960a). Coeliac disease. Gut, 1, 48.

- (1960b). Histopathology in Coeliac Disease. Proceedings of the International Congress of Gastroenterology, Leyden, Holland, April 20-24. In the press.

Gastroenterology, 38, 419.

Zetterquist, H.(1956). The Ultrastructural Organisation of the Columnar Absorbing Cells of the Mouse Jejunum. Thesis from the Department of Anatomy, Karolinska Institute, Stockholm, Sweden.

—, and Hendrix, T. R. (1960). Bull. Johns Hopk. Hosp., 106, 240.

\section{CORRECTION}

In Table I of the paper entitled 'A clinical appraisal of the treatment of chronic duodenal ulcer by vagotomy and gastric drainage operation' by W. Gerald Austen and Harold C. Edwards on page 158 of the June issues, the word 'pyloroplasty' has been incorrectly repeated. The relevant line of Table I should read:-

Type of operation performed with vagotomy

Gastroenterostomy 90

Pyloroplasty 